\title{
PENGGUNAAN TTS MENINGKATKANKAN HASIL BELAJAR DALAM MEMAHAMI CERITA ANAK PADA ANAK TUNAGRAHITA RINGAN DI SPLB- C YPLB
}

\author{
EVI SUKMIROH \\ SPLB C YPLB Cipaganti, Kota Bandung \\ Email : evisukmiroh99@gmail.com
}

\begin{abstract}
ABSTRAK
Penelitian ini bertujuan untuk mengetahui hasil belajar Bahasa Indonesia Kompetensi Dasar Memahami cerita Anak. Setelah penggunaan alat peraga Teka-Teki Silang pada siswa tunagrahita. Subjek dalam penelitian ini adalah siswa tunagrahita kelas X SMALB-C yang berjumlah 3 orang, terdiri dari 3 orang siswa perempuan. Penelitian tindakan kelas ini dilaksanakan di SPLB-C YPLB Cipaganti Kota Bandung dengan oserver seorang guru yang berinisial DD. Berdasarkan hasil penelitian, bahwa penggunaan alat peraga Teka-Teki Silang dapat meningkatkan hasil belajar Bahasa Indonesia kompetensi Dasar Memahami cerita Rakyat. Penggunaan alat peraga ini membantu meningkatkan konsentarasi siswa dan motivasi, menumbuhkan susasana pembelajaran yang penuh kegembiraan dan siswa lebih tertarik untuk belajar dalam waktu yang relatif cukup lama. Penelitian tindakan kelas ini dilaksanakan dalam tiga siklus, dengan masing-masing siklus satu pertemuan dan meliputi empat tahapan, yaitu : tahap perencanaan, tindakan, observasi dan refleksi. Mengacu pada tujuan penelitian ini, maka instrumen penelitian yang digunakan dalam penelitian ini adalah tes dan non tes. Tes digunakan untuk melihat peningkatan hasil belajar Bahasa Indonesia Kompetensi Dasar Memahami cerita anak, sedangkan non tes digunakan untuk melihat peningkatan kualitas proses pembelajaran yang dicerminkan oleh sikap anak dalam pembelajaran, aktivitas siswa dan aktivitas guru saat pembelajaran. Dari data yang diperoleh selama penelitian kemudian diolah dan dianalisis, diperoleh hasil yang menunjukan adanya peningkatan hasil belajar belajar. Bahasa Indonesia. dengan Kompentensi Dasar Memahami cerita Anak. terdapat perbedaan yang cukup signifikan. Adapun skor yang dicapai sebelum perbaikan adalah $43 \%$, pada siklus 1 sebesar 55\%, pada siklus 2 sebesar $76 \%$ dan pada siklus 3 sebesar $90 \%$. Dari skor yang diperoleh pada siklus 3 yaitu $90 \%$ sudah melebihi kriteria ketuntasan minimal yang telah ditentukan diawal penelitian yaitu sebesar 70\%. Dengan demikian hasil tersebut menunjukan bahwa penggunaan alat peraga Teka-Teki Silang dapat meningkatkan hasil belajar belajar Bahasa Indonesia dengan Kompetensi Dasar Memahami cerita Anak pada siswa tunagrahita kelas X SMALB-C di SPLBC YPLB Cipaganti Kota Bandung

Kata kunci: TTS, Hasil Belajar , Tes, Tunagrahita, Cerita anak
\end{abstract}

\section{ABSTRACT}

This study aims to determine the learning outcomes of Indonesian Basic Competence in Understanding Children's Stories. After the use of crossword puzzles for mentally retarded students. The subjects in this study were mentally retarded students in class X SMALB-C, totaling 3 people, consisting of 3 female students. This classroom action research was carried out at SPLB-C YPLB Cipaganti, Bandung City with the supervisor of a teacher with the initials DD. Based on the results of the study, that the use of crossword puzzles can improve learning outcomes of Indonesian Language Basic Competence Understanding Folklore. The use of these teaching aids helps increase student concentration and motivation, fosters a joyful learning atmosphere and students are more interested in learning in a relatively long time. This classroom action research was carried out in three cycles, with each cycle having one meeting and covering four stages, namely: planning, action, observation and reflection stages. Referring to the purpose of this study, the research instruments used in this study were tests and non-tests. The test is used to see the increase in learning outcomes of Indonesian Basic Competence Understanding children's stories, while the non-test is used to see the improvement in the quality 
of the learning process which is reflected by the attitudes of children in learning, student activities and teacher activities during learning. From the data obtained during the study and then processed and analyzed, the results showed that there was an increase in learning outcomes. Indonesian. with Basic Competence Understanding Children's stories. there is a significant difference. The score achieved before the improvement was $43 \%$, in cycle 1 it was $55 \%$, in cycle 2 it was $76 \%$ and in cycle 3 it was $90 \%$. From the score obtained in cycle 3, which is $90 \%$, it has exceeded the minimum completeness criteria that have been determined at the beginning of the study, which is $70 \%$. Thus, these results indicate that the use of crossword puzzles can improve learning outcomes of Indonesian language learning with Basic Competence in Understanding Children's Stories for mentally retarded students in class X SMALB-C at SPLB-C YPLB Cipaganti, Bandung City.

Key words: TTS, Learning Outcomes, Tests, Mental retardation, Children's stories

\section{PENDAHULUAN}

Berdasarkan kenyataan di lapangan bahwa banyak siswa berusaha untuk mengisi jam istirahatnya dengan makan dan bersenda gurau dengan siswa yang lain maupun dengan guru dan sering bermain game atau puzzle yang ada disekolah. Dengan cara permainan siswa lebih senang dan meningkatkan motivasi untuk belajar dan menjawab soal atau game yang dilakukan permainan berupa teka-teki sangat di senangi dan diminati siswa.

Perbedaan individual di Sekolah luar biasa sangat unik dan beragam anak yang sudah mampu baca dalam pemahamannya akan berbeda walaupun sama sudah bisa baca. Jadi metode pembelajarannya juga harus per individu, seperti yang di kemukaan oleh Seorang pakar pendidikan luar biasa.

"Pembelajaran anak berkebutuhan khusus (student with special needs) membutuhkan suatu pola tersendiri sesuai dengan kebutuhannya masing-masing, yang berbeda antara satu dan yang lainnya" (Delphie, 2006:7).

Siswa Sekolah luar biasa unik dalam segala potensi akademik, kemampuan motorik, halus, kemampuan motorik kasar, emosi dan perkembangan bahasanya. "Perubahan tingkah laku merupakan proses pembelajaran yang di peroleh melalui penalamanindividuyang bersangkutan Tumpuan perhatian ahli psikologi pembelajaran adalahmengapa,dan bagaimana prosespembelajaran berlaku" (Asori, 2008:28)

Permasalahan yang dihadapi rendahnya hasil belajar dan kurang minat siwa dalam pembelajaran bahasa terutama terhadap materi pemahaman isi bacaan, kegiatan yang monoton yang di lakukan seperti metode ceramah dan kegiatan yang tidak menggali kemampuan siswa secara aktif sehingga menghasilkan pemahaman yang kurang. Dengan menggunakan metode ceramah pengetahuan yang didapat mudah dilupakan. Penjelasan guru ketika menjelaskan materi pembelajaran kurang jelas dan Siswa kurang mengerti perintah baik secara lisan maupun tulisan.

Memilih metode dan pemanfaatan metode pembelajaran yang tepat diusahan akan ada peningkatan hasil belajar dalam pemahaman isi bacaan. Kenyataan dilapangan hasil ulangan harian dalam memahami materi bacaan tidak dapat melebihhi kkm yang mampu diserap siswa 43\% sehingga peneliti mencoba menerapakan TTS ini sebagai jalan mengatasi masalah yang dihadapi di kelas peneliti. Guru harus mampu memberikan pembelajaran yang efektif yang mampu memberikan makna bagi kehidupannya sehari-hari.. Metode yang bervariatif akan mampu menikatkan daya serap dalam menerima respon.

Alat peraga yang tepat sangat membantu diperlukan untuk meningkatkan motivasi siswa dalam belajar, Sehingga diharapkan hasil belajar akan lebih baik

Kegiatan Penelitian bertujuan untuk mendeskripsikan, menemukan kebiasan penggunaan alat peraga Teka-Teki Silang dalam pembelajaran Bahasa Indonesia dapat memotivasi pendidik dan siswa untuk saling belajar serta meningkatkan pengetahuan dan pemahaman siswa. Secara khusus untuk meningkatkan perhatian dan keterlibatan siswa kelas 
$\mathrm{X}$ dalam pembelajaran Bahasa Indonesia lebih bermakna dan Membiasakan belajar mandiri dan berpikir ilmiah tidak meniru/mencontek dari teman atau membeo dari guru.

Dengan latar belakang masalah untuk mengatasi masalah maka peneliti mencoba mengatasi suatu permasalah dengan suatu tindakan yaitu penggunaan TTS mampu meningkakatkan hasil belajar memahami materi bacaan dan berpengaruh juga terhadap minat dan konsentrasi belajar siswa.

\section{METODE PENELITIAN}

Metode yang digunakan dalam penelitian ini adalah metode deskriptif kualitatif. Metode deskriptif kualitatif mempunyai arti bahwa penelitian yang dimaksud berusaha mengungkapkan jawaban atas permasalahan yang terjadi pada saat ini melalui suatu tindakan yang terencana dan terlaksana melalui siklus tindakan. Adapun prosedur yang ditempuh dalam penelitian tindakan kelas ini penulis menentukan beberapa tahap. Subjek penelitian dalam proses pelaksanaan Penelitian Tindakan Kelas ini diikuti oleh 3 orang siswa tunagrahita ringan kelas X SMALB-C SPLB-C YPLB Cipaganti. Lokasi penelitian di kelas X SMALB-C SPLB-C YPLB Cipaganti. Adapunwaktu penelitian dilakukan pada semester II ( genap) tahun pelajaran 2017-2018. Jumlah siklus penelitiandilihat dari hasil analisis data yang menjadi acuan penelitian dalam proses refleksi penelitian tindakan kelas.

Prosedur penelitian sebagai alat untuk mengumpulkan data yang diteliti adalah menggunakan pedoman observasi/pengamatan. Lembar observasi ini adalah merupakan instrumen untuk mencatat data-data yang diteliti sesuai dengan kejadian pada saat proses pembelajaran berlangsung. Pada lembar observasi ini berisi tentang pernyataan-pernyataan yang sesuai dengan indikator-indikator penelitian sebagaimana tertuang dalam kisi-kisi instrumen penelitian. Untuk memperoleh data-data yang diperlukan menggunakan teknikteknik sebagai berikut :

1. Studi Kepustakaan, yaitu untuk memperoleh keterangan-keterangan ilmiah dari bukubuku sumber yang ditulis para ahli, karangan ilmiah, dan internet yangberkaitan dengan masalah yang diteliti.

2. Observasi/pengamatan, yaitu suatu teknik pengumpulan data dengan menggunakan pedoman observasi yang berisi tentang permasalahan yang diteliti, yaitu tentang efektivitas penggunaan alat peraga TTS dalam proses pembelajaran.

Dalam pelaksanaanya ada kemungkinan peneliti telah mempunyai seperangkat tindakan (yang didasarkan pada pengalaman) sehingga langsung memulai tahap tindakan. Ada juga peneliti yang telah memiliki seperangkat data sehingga mereka memulai kegiatan pertamanya dengan kegiatan refleksi. Akan tetapi pada umumnya para peneliti mulai dari refleksi awal untuk melakukan studi pendahuluan penelitian.Selanjutnya diikuti perencanaan,tindakan,observasi dan refleksi.

Penyusunan perencanaan didasarkan pada hasil penjajagan refleksi awal. Secara rinci perencanaan mencakup tindakan yang akan dilakukan untuk memperbaiki, meningkatkan atau merubah perilaku dan sikap yang diinginkan sebagai solusi dari permasalahanpermasalahan.Perlu disadari bahwa perencanaan ini bersifat fleksibel dalam arti dapat berubah sesuai dengan kondisi nyata yang ada. Berupa RPP, alat dan media pembelajaran (TTS), dan lembar observasi.

\section{HASIL DAN PEMBAHASAN}

\section{Hasil}

Desain PTK yang dilakukan menurut Kemmis dan Mc Taggart (dalam Rafi'udin,1996) penelitian dipandang sebagai suatu siklus spiral dari penyusunan perencanaan, pelaksanaan, tindakan, pengamatan (observasi) dan refleksi yang selanjutnya mungkin diikuti siklus spiral berikutnya. Dalam pelaksanaanya ada kemungkinan peneliti telah mempunyai seperangkat tindakan (yang didasarkan pada pengalaman) sehingga langsung memulai tahap tindakan. Ada juga peneliti yang telah memiliki seperangkat data sehingga mereka memulai kegiatan 
pertamanya dengan kegiatan refleksi. Akan tetapi pada umumnya para peneliti mulai dari refleksi awal untuk melakukan studi pendahuluan sebagai dasar dalam merumuskan masalah penelitian. Selanjutnya diikuti Perencanaan,tindakan,observasi dan refleksi Pada siklus 1 ini penelitian dilakukan dengan empat tahap, yaitu perencanaan, pelaksanaan, observasi / pengamatan dan refleksi. Siklus 1 ini penelitian berlangsung dalam satu pertemuan, hasil penelitian pada siklus 1 ini adalah sebagai berikut:

Perencanaan rencana perbaikan pembelajaran yang dilakukan pada siklus 1 dengan cara menentukan jumlah pertemuan yang akan dilaksanakan dalam siklus, pertemuan yang dilakukan dalam siklus 1 ini sebanyak satu pertemuan, membuat lembar observasi untuk siklus 1, menyiapkan media TTS untuk siklus 1 membuat alat evaluasi belajar untuk mengetahui kemampuan anak tunagrahita dalam memahami isi cerita anak melalui TTS, melaksanakan simulasi mengajar perbaikan pembelajaran pada siklus 1, menentukan waktu pelaksanaan perbaikan pembelajaran bersama observer untuk siklus 1, menentukan jadwal untuk refleksi dan menyiapkan poin-poin yang akan dibahas dalam refleksi.

Dalam perencanaan awal guru menyusun skenario pembelajaran dan membuat media TTS dengan menggunakan berukuran kecil yang digunakan untuk perlakuan terhadap peserta didik. Di samping itu disiapkan pula alat evaluasi untuk mengetahui keberhasilan peserta didik berupa lembar kerja siswa.

Pelaksanaan tindakan merupakan implementasi dari semua rencana yang telah dibuat pada perencanaan tindakan yang berlangsung di dalam kelas. Saat pelaksanaan siklus 1 ini, peserta didik hadir semua yaitu sebanyak 3 orang dan dalam pelaksanaan tindakan ini adanya keterlibatan teman sejawat sebagai observer sekedar membantu peneliti dalam mengamati pelaksanaan perbaikan pembelajaran yang dilaksanakan.

Kegiatan pembelajaran di awali dengan mengkondisikan peserta didik dan melakukan percakapan sebagai appersepsi, setelah itu guru mulai membimbing cara mengisi kotak-kotak TTS dengan jawaban dari cerita yang telah di baca secara menurun dan mendatar. Koreksi jawaban individu dilakukan untuk mengetahui tingkat kemajuan dan sekaligus kekurangan peserta didik. Dari hasil ini dapat diketahui tingkat kemampuan peserta didik dalam menjawab pemahaman cerita anak.

Berdasarkan hasil pekerjaan peserta didik, lalu diadakan pembahasan soal secara bersama. Dimaksudkan agar peserta didik benar - benar dapat memahami pemecahan soal soal tersebut. Selanjutnya dilakukan tes uji coba untuk mengetahui perkembangan kemampuan peserta didik dalam mengerjakan soal essai. Untuk lebih jelasnya data hasil belajar pada siklus 1 akan dibandingkan dengan data hasil belajar sebelum siklus (sebelum perbaikan pembelajaran), adapun hasilnya adalah sebagai berikut :

Tabel 1. Perbandingan Nilai Awal dengan Nilai Siklus 1,II dan III

\begin{tabular}{|l|l|l|l|l|l|}
\hline \multirow{2}{*}{ No } & \multirow{2}{*}{$\begin{array}{c}\text { Kode } \\
\text { Siswa }\end{array}$} & \multicolumn{4}{c|}{ NILAI } \\
\cline { 3 - 6 } & & $\begin{array}{c}\text { Kondisi } \\
\text { awal }\end{array}$ & Siklus I & Siklus II & $\begin{array}{c}\text { Siklus } \\
\text { III }\end{array}$ \\
\hline $\mathbf{1}$ & TA & $\mathbf{3}$ & $\mathbf{3}$ & $\mathbf{6}$ & $\mathbf{8}$ \\
\hline $\mathbf{2}$ & SN & $\mathbf{6}$ & $\mathbf{6}$ & $\mathbf{9}$ & $\mathbf{1 0}$ \\
\hline 3 & MA & $\mathbf{4}$ & $\mathbf{4}$ & $\mathbf{8}$ & $\mathbf{9}$ \\
\hline
\end{tabular}

\begin{tabular}{|c|c|c|c|c|}
\hline \multirow{2}{*}{$\begin{array}{l}\text { Jumlah } \\
\text { Rata-rata }\end{array}$} & 4,3 & 4,3 & 7,6 & 9 \\
\hline & 4,3 & 4,3 & 7.6 & 9 \\
\hline Belum tuntas & 2 & 2 & $\mathbf{0}$ & $\mathbf{0}$ \\
\hline $\begin{array}{l}\text { Prosentasi belum } \\
\text { tuntas }\end{array}$ & $\mathbf{5 0 \%}$ & $50 \%$ & $\mathbf{0}$ & $\mathbf{0}$ \\
\hline Prosentasi tuntas & $\mathbf{5 0 \%}$ & $50 \%$ & $100 \%$ & $100 \%$ \\
\hline
\end{tabular}


Berdasarkan tabel di atas diketahui nilai awal peserta didik dalam kemampuan memahami soal essai yaitu rata-rata 4,3 atau persentase 5\%. Hal ini menunjukan kemampuan awal peserta didik dalam hal memahami cerita anak dan menjawab soal secara menurun dan mendatar masih rendah. Sedangkan setelah adanya penerapan media TTS pada siklus 1 nilai rata-rata penguasaan materi adalah 4,3 atau dengan persentase $50 \%$, dengan rata-rata peningkatan dari nilai awal ke hasil tes siklus 1 sebesar 5\%. Dari adanya peningkatan tersebut menunjukan bahwa penerapan media bermain TTS sudah dapat meningkatkan kemampuan tunagrahita dalam memahami Cerita Anak, meskipun peningkatannya belum sempurna. Pada siklus 1 ke siklus 2 mengalami peningkatan sebesar $33 \%$ nilai rata-rata 4,3 meningkat menjadi 7,6 ini didapat dari ini kemampuan memahami bagian-bagian tubuh hewan yang dikuasai lebih banyak pada aspek menyebutkan bagian-bagian tubuh hewan nya saja itupun setelah digabungkan menjadi satu bagian yang utuh pada TTS. Sedangkan dari siklus 2 ke siklus 3 didapat peningkatan nilai rata-rata dari 7,6 menjadi 9 kalau di prosentasikan nilainya sebesar $14 \%$

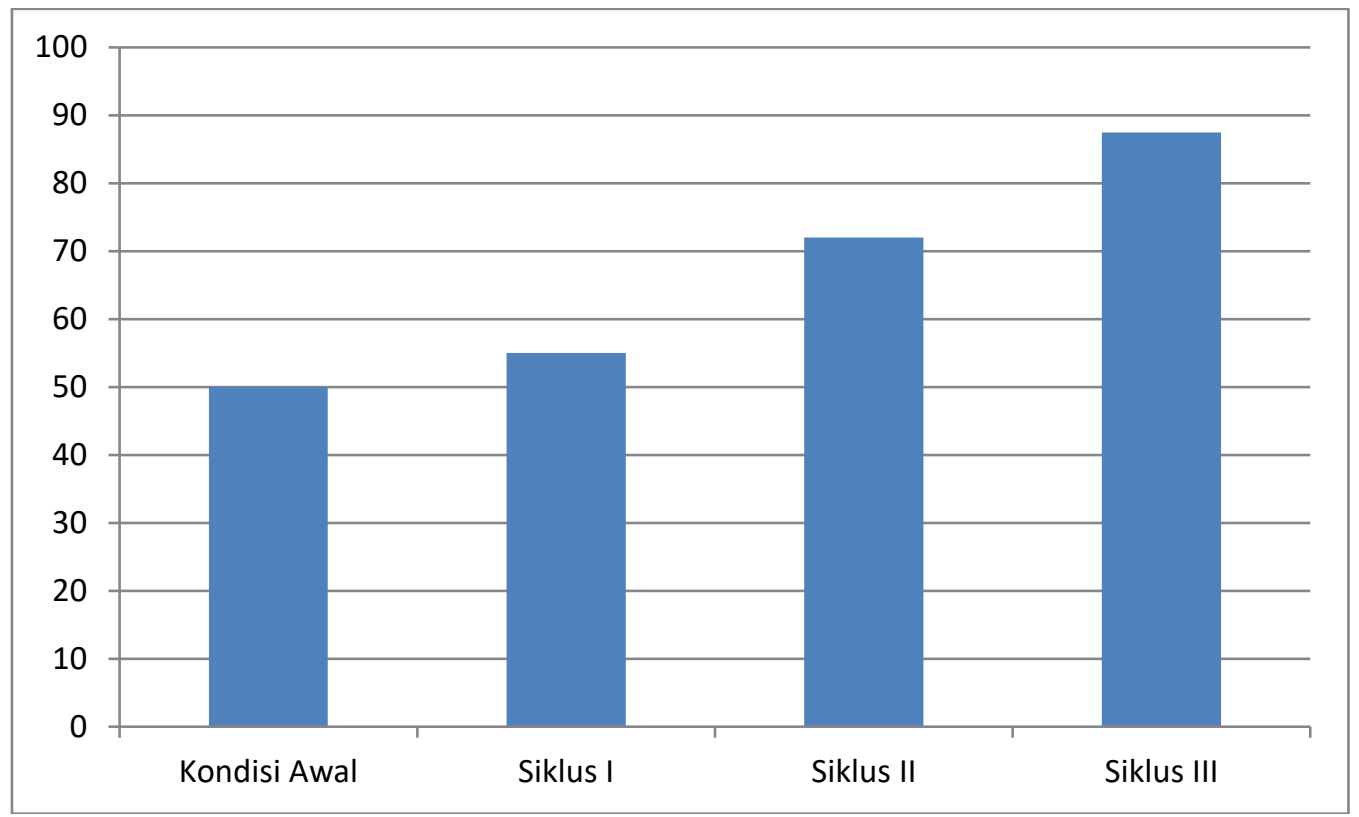

\section{Gambar 1. Grafik Perkembangan Rata-rata Hasil Belajar Siswa Melalui media TTS dalam Pembelajaran Bahasa Indonesia}

\section{Pembahasan}

Berdasarkan hasil analisis data dari mulai kemampuan awal sampai pada akhir siklus 3 yang telah diuraikan sebelumnya diperoleh hasil penilaian bahwa penerapan media menyusun jawaban melalui TTS dapat memberikan pengaruh yang signifikan terhadap peningkatan kemampuan memahami cerita anak pada peserta didik tunagrahita di kelas X SMALB-C SPLBC YPLB Cipaganti Kota Bandung.

Berdasarkan pengamatan, hal tersebut dipengaruhi oleh beberapa faktor, diantaranya : (1). Motivasi belajar peserta didik selama proses pembelajaran berlangsung. (2). Media pembelajaran yang digunakan dapat menunjang proses pembelajaran dan membantu meningkatan motivasi belajar peserta didik, hal ini sejalan dengan yang diungkapkan Sudjana (Arsyad, 2007:24) yaitu pembelajaran akan lebih menarik perhatian peserta didik sehingga dapat menumbuhkan motivasi belajar. (3). Tingkat Intelegensi peserta didik anak tunagrahita berpengaruh terhadap kemampuan berfikir logisnya.

Kegiatan menyusun TTS merupakan hal yang disukai tunagrahita daripada teori, karena konsep bermain sambil belajar akan menciptakan suasana yang menyenangkan dan sesuai dengan dunia anak-anak pada jenjang pendidikan dasar dasar. Soal yang digunakan sebagai instrument penelitian tidak lagi menjadi beban peserta didik, karena peserta didik sudah mengetahui bagaimana cara mengerjakan soal essai. 
Berdasarkan hasil pengolahan dan analisis data diketahui bahwa pada penelitian yang telah dilakukan dengan media Teka-Teki Silang l dapat membantu meningkatkan kemampuan memahami soal cerita peserta didik tunagrahita di SPLB-C YPLB Cipaganti Kota Bandung.

Penerapan media dalam meningkatkan kemampuan memahami cerita anak peserta didik tunagrahita mempunyai kelebihan dan kelemahan. Adapun kelebihan dalam pendekatan ini yaitu ; (1) Komunikasi merupakan hal biasa dilakukan dalam kehidupan sehari-hari, sehingga proses pembelajaran dengan media mampu menciptakan suasana belajar sambil bermain. (2). Bermain TTS dan diskusi merupakan implementasi dari teori yang sudah dipelajari sebelumnya dan gambaran seberapa jauh materi dapat dipahami peserta didik. (3). Suasana yang santai dan menyenangkan membuat peserta didik tidak mudah bosan. Sedangkan kelemahannya yaitu tanpa pengawasan dan manajemen yang baik, maka subjek akan larut dalam TTS dan tidak menghubunghan dengan materi pembelajaran yang harus dicapai dalam kompetensi dasar dan tujuan pembelajaran yang diharapkan.

\section{KESIMPULAN}

Dari hasil kegiatan pembelajaran yang telah dilakukan selama tiga siklus, dan berdasarkan seluruh pembahasan serta analisis yang telah dilakukan dapat disimpulkan sebagai berikut :

Pembelajaran dengan alat Teka-teki Silang memiliki dampak positif dalam meningkatkan prestasi belajar siswa yang ditandai dengan peningkatan nilai belajar siswa dalam setiap siklus. Pengunaan alat peraga TTS juga telah memberikan dampak yang positif terhadap sikap siswa dalam belajar konsentrasi , motivasi pun lebih meningkat. Di mana sebelum penggunaan TTS pembelajaran ini, siswa pasif dan individual ketika belajar, tetapi setelah penggunaan alat peraga TTS pembelajaran ini dalam 3 siklus, siswa semakin aktif dan memotivasi siswa untuk belajar Bahasa Indonesia.

Hasil penelitian yang diperoleh dan uraian sebelumnya agar proses belajar mengajar Bahasa Indonesia lebih efektif dan lebih memberikan hasil yang optimal bagi siswa, maka disampaikan saran sebagai berikut:

Untuk melaksanakan pembelajaran Bahasa Indonesia memerlukan persiapan yang cukup matang, sehingga guru harus mampu menentukan atau memilih alat peraga yang benarbenar bisa diterapkan sesuai dengan materi pembelajaran sehingga proses belajar mengajar sehingga diperoleh hasil yang optimal.

Dalam rangka meningkatkan prestasi belajar siswa, guru hendaknya lebih sering melatih siswa tunagrahita untuk belajar sambil bermain dan menerapkan / TTS ini pada beberapa pelajaran yang meningkatkan kemampuan mengingat, konsentrasi dan motivasi unutk belajar. Sebagai penguatan bahwa TTS ini merupakan media yang cocok untuk pembelajaran bahasa, penulis melihat juga pada jurnal yang telah di publikasikan yaitu Jurnal Peningkatan kosa-kata melalui teknik permaian teka-teki silang, dimana rat-rata peningkatan setelah digunakan TTS adalah Prasiklus $=53,9$, dan sikus 1 69,50 dan siklus 2 menjadi 75,23 jadi dapat di simpulkan bahwa TTS mampu meningkat prestasi belajar bahasa.

\section{DAFTAR PUSTAKA}

Depdikbud. (1994). Program Kegiatan Belajar Taman Kanak-Kanak. Jakarta : Depdikbud.

Delphie, P. (2006). Pembelajaran Anak Berkebutuhan Khusus (dalam Setting Pendidikan Inklusi). Bandung: PT. Refika Aditama.

Yulia Elviza., Emidar Emidar., Ena Noveria. (2013). Peningkatan Penguasaan Kosakata Melalui Teknik Permainan Teka-teki Silang di Kelas VII.A SMPN 2 Sungai Penuh. Jurnal Pendidikan Bahasa dan Sastra Indonesia, Vol 1 No 2.

Hamalik, Oemar. 2002. Psikologi Belajar dan Mengajar. Bandung: Sinar Baru Algesindo., Joyce, Bruce dan Weil, Marsh. 1972. Models of Teaching Model. Boston: A Liyn dan Bacon. Nur, Moh. 2001. Pemotivasian Siswa untuk Belajar. Surabaya. University Press. Universitas Negeri Surabaya. 
Nana Sudjana. (2002). Alat Peraga dan Kegunaannya, Bandung : Universitas Pendidikan Indonesia

Nana Sudjana. (2009). Pedoman Peulisan Karya Ilmiah. Bandung : UPI

Suryosubroto, B. 1997. Proses Belajar Mengajar di Sekolah. Jakarta: PT. Rineksa Cipta.

Tarigan. 1986. Keterampilan Berbahasa. Bandung : Angkasa

Usman, Uzer. 2000. Menjadi Guru Profesional. Bandung : PT. Remaja Rosdakarya.

Widoko. 2002. Metode Pembelajaran Konsep. Surabaya: Universitas Negeri Surabaya 